\title{
The change in the leaf conducting system of the winter wheat samples under the conditions of simulated drought
}

\author{
Elena Ionova ${ }^{1}$, Valentina Likhovidova ${ }^{1,{ }^{*}}$, Valentina Gaze $^{1}$, Aleksey Popov ${ }^{1}$ \\ ${ }^{1}$ Agricultural Research Center “Donskoy”, 3, Nauchny Gorodok, 347740, Zernograd, Russia
}

\begin{abstract}
The current paper has considered the effect of the development degree of the leaf conducting systems and the head-bearing internode on kernel weight per head of the winter wheat grown in the conditions of insufficient moisture supply and optimal moisture. The study of out among 13 winter wheat samples developed by the FSBSI "Agricultural Research Center "Donskoy". The area of the conducting vascular bundle of winter wheat ranged from $0.208 \mathrm{~mm}^{2} 10^{-4}$ ('Shef', '586/13') to $0.364 \mathrm{~mm}^{2} 10^{-4}$ ('Krasa Dona') (a trial) and from $0.381 \mathrm{~mm}^{2} 10^{-4}$ ('Etyud') to $0.350 \mathrm{~mm}^{2}$ $10^{-4}$ ('Zhavoronok') (a control). The maximum development degree of wheat leaf conducting system in the trials was identified in the varieties 'Krasa Dona' (4.01 $\left.\mathrm{mm}^{2} 10^{-4}\right)$ and 'Ambar' $\left(4.22 \mathrm{~mm}^{2} 10^{-4}\right)$, and in the control these were the varieties 'Polina' $\left(2.59 \mathrm{~mm}^{2} 10^{-4}\right)$ and 'Ambar' $\left(2.62 \mathrm{~mm}^{2} 10^{-4}\right)$. The maximum values of the area of the leaf conducting system and kernel weight per head were shown by the varieties 'Krasa Dona' $\left(4.01 \mathrm{~mm}^{2} 10^{-4}\right.$ and $\left.0.37 \mathrm{~g}\right)$ and 'Ambar' $\left(4.22 \mathrm{~mm}^{2} 10^{-4}\right.$ and $\left.0.39 \mathrm{~g}\right)$.
\end{abstract}

\section{Introduction}

The conducting vascular bundles form a leaf venation, they supply salt solutions and water to the mesophyll, and also carry out the outflow of plastic substances obtained in assimilation [1]. The leaf conducting system is presented in the form of venation, especially characteristic for a reverse side of a leaf blade. The location of the conducting vascular bundles (venation) gives a characteristic appearance to a leaf blade [1]. The leaves with parallel venation (monocotyledonous plants), the vascular bundles are of the same size, they are connected either in the upper part of the leaf or on both sides of the blade. This is due to the conductive tissues, that all organs of the plant have a normal functioning [2]. The leaf and stem conducting systems supply plants with water and distribute assimilants [1]. A small number of the conducting vascular bundles and their area slows down the movement and accumulation of assimilants in plants and often cause a productivity decrease of grain crops in conditions of soil and air drought [3]. The study of various plant systems in conditions of insufficient moisture supply is of great importance, since it has been established that in dry conditions plant productivity is significantly reduced. This is

*Corresponding author: valya_17@rambler.ru 
primarily connected with the distorted functions of plant growth, respiration, photosynthesis and transpiration of assimilants [5].

The purpose of the current study was to establish the effect of the development degree of the leaf and stem conducting systems under the conditions of simulated drought on winter wheat productivity.

\section{Materials and methods}

The current study was carried out in arid conditions of simulated drought in 2016-2019. The objects of the study were 13 winter wheat varieties and lines developed by the FSBSI "Agricultural Research Center "Donskoy". The study was conducted on the head-bearing internodes and flag leaves in the flowering period of wheat according to the method of Ionova E.V. [4]. The study of the development degree of the leaf conducting system of the winter wheat samples was carried out under conditions of simulated drought in the laboratory of plant physiology of the "ARC "Donskoy", Maimistov V.V. (1984).

\section{Results and discussion}

Productivity increase of the new winter wheat varieties made it possible to find out which physiological systems influenced their productivity rise. It was carried out a study to assess the development degree of the conducting systems of the head-bearing internode of the stem and leaf of winter wheat under various conditions of moisture supply [6,7]. The conducting system of the wheat stem and leaves has a structure which is characteristic for all grain crops (Figure 1,2).

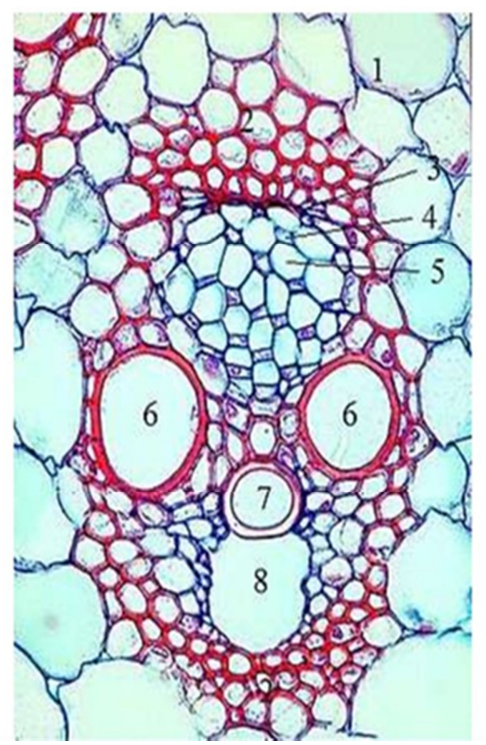

(A)

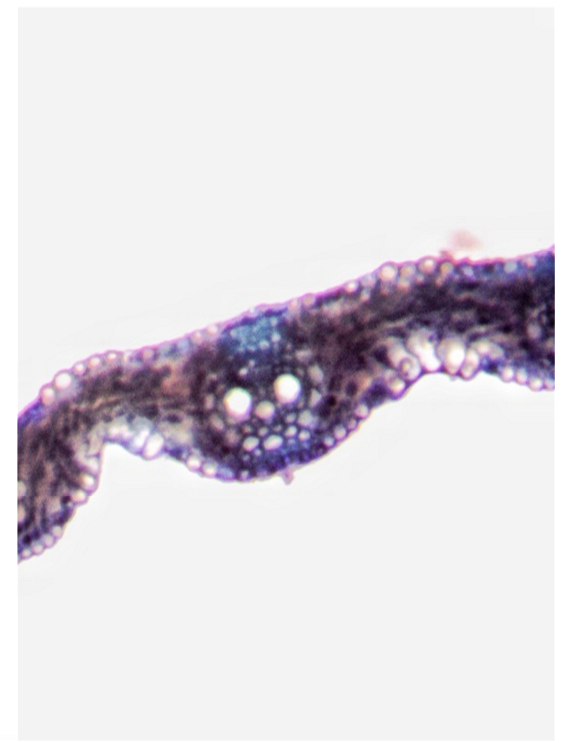

(B)

A - Structure of conducting vascular bundles of a winter wheat leaf blade.

1 - parenchyma; 2 - sclerenchyma; 3- cribriform element of protofloem; 4 -accompanying cell; 5 - cribriform (sieve) tube; 6 - metaxilema vessel; 7 - metaxilema trachea; 8 - protoxylem vessel.

$\mathrm{B}-$ Cross section of a winter wheat leaf.

Fig. 1. The structure of a leaf conducting system. 

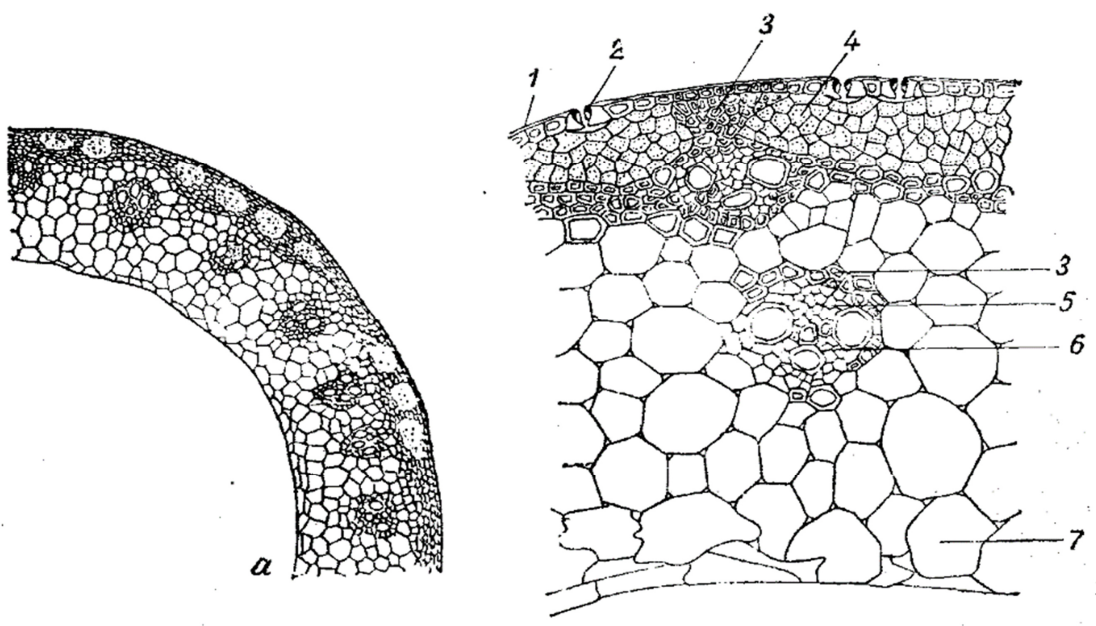

Fig. 2. The structure of a wheat stem: $a$ - cross section of a stem part at low magnification; $b$ - cross section of a stem part at high magnification; 1 - epidermis; 2 - stoma; 3 - sclerenchyma; 4 chlorenchyma; 5 - phloem; 6 - xilema; 7 - parenchyma.

The bundles consist of primary xylem and phloem arising from procambium, and are usually combined in closed collateral bundles. The xylem of the bundle is characterized by the presence of two large cribriform vessels, between which there are smaller spiral and annular vessels closer to the center. The latter is not easy to detect, since it often undergoes destruction (like the nearby cells), resulting in a small cavity that is always clearly visible in the xylem part of the bundle $[8,7]$. Under conditions of insufficient water supply (a trial), the number of conducting bundles varied from 9 to 17 pcs. (Table 1).

Table 1. The change of the number and area of conducting bundles of the winter wheat varieties in dependence of growing conditions.

\begin{tabular}{|c|c|c|c|c|}
\hline \multirow{2}{*}{ Sample } & \multicolumn{2}{|c|}{$\begin{array}{c}\text { Area of one bundle. } \\
\mathbf{m m}^{\mathbf{2}} \mathbf{1 0}^{-\mathbf{4}}\end{array}$} & \multicolumn{2}{c|}{$\begin{array}{c}\text { Number of bundles. } \\
\text { pcs. }\end{array}$} \\
\cline { 2 - 5 } & a trial & a control & a trial & a control \\
\hline Ambar & 0.301 & 0.374 & 14 & 7 \\
\hline Zhavoronok & 0.260 & 0.350 & 14 & 7 \\
\hline Luchezar & 0.239 & 0.367 & 16 & 6 \\
\hline $1232 / 13$ & 0.353 & 0.373 & 11 & 6 \\
\hline Krasa Dona & 0.364 & 0.368 & 11 & 6 \\
\hline Shef & 0.208 & 0.371 & 17 & 6 \\
\hline Donskaya Step & 0.351 & 0.367 & 10 & 6 \\
\hline Asket & 0.263 & 0.361 & 13 & 5 \\
\hline Etyud & 0.352 & 0.381 & 10 & 6 \\
\hline $1756 / 13$ & 0.363 & 0.362 & 11 & 7 \\
\hline Volny Don & 0.303 & 0.370 & 9 & 6 \\
\hline $586 / 13$ & 0.208 & 0.369 & 15 & 6 \\
\hline Polina & 0.245 & 0.370 & 12 & 7 \\
\hline
\end{tabular}

The varieties 'Luchezar' (16 pcs.) and 'Shef' (17 pcs.) showed the maximum number of conducting bundles of a flag leaf. In comparison with the variety-classifier 'Asket', the varieties 'Shef' ( +4 pcs.), 'Luchezar' (+3 pcs.), '586/13' (+2 pcs.) formed a larger number of conducting bundles under drought. Under conditions of optimal moisture (a control) the studied wheat varieties did not have great differences in the number of conducting bundles, the numbers ranged from 5 to 7 pieces. It should be noted that under conditions of sufficient 
moisture supply (a control), the wheat plants formed an almost identical leaf conducting system with smaller sizes and the number of conducting bundles in comparison with a conducting system formed under conditions of insufficient moisture supply (a trial). Such a number of bundles and their total area was sufficient for optimal supply of the head with assimilants. The moisture presence in soil affected the development degree of the conducting system of wheat plants [9]. The area of the conducting bundle ranged from $0.208 \mathrm{~mm}^{2} 10^{-4}$ ('Shef', '586/13') to $0.364 \mathrm{~mm}^{2} 10^{-4}$ ('Krasa Dona') (a trial) and from 0.350 $\mathrm{mm}^{2} 10^{-4}$ ('Zhavoronok') to $0.381 \mathrm{~mm}^{2} 10^{-4}$ (Etyud) (a control). The maximum area of one bundle under conditions of insufficient moisture supply was formed by the varieties 'Krasa Dona' $\left(0.364 \mathrm{~mm}^{2} 10^{-4}\right)$ and ' $1756 / 13$ ' $\left(0.363 \mathrm{~mm}^{2} 10^{-4}\right)$, and under conditions of optimal moisture these were the varieties 'Etyud' $\left(0.381 \mathrm{~mm}^{2} 10^{-4}\right)$ and 'Ambar' $\left(0.374 \mathrm{~mm}^{2} 10^{-4}\right)$. Among the studied samples, 8 samples exceeded the area of the conducting bundle on 0.01$0.8 \mathrm{~mm}^{2} 10^{-4}$ in comparison with the variety-classifier 'Asket' (a trial). Under conditions of long water scarcity, the area of conducting bundles reduced in the samples less tolerant to drought ('Shef', '586/13'), which led to a decrease in transpiration and gas exchange of plants.

The development of the head-bearing internode of the winter wheat samples under conditions of insufficient moisture supply had the same patterns as the development of the leaf conducting system [10,9]. Under conditions of insufficient moisture supply, the varieties formed a total area of the leaf conducting system from $2.94 \mathrm{~mm}^{2} 10^{-4}$ ('Polina') to $4.22 \mathrm{~mm}^{2} 10^{-4}$ ('Ambar'). In the trial the maximum development degree of the leaf conducting system was identified in the varieties 'Krasa Dona' $\left(4.01 \mathrm{~mm}^{2} 10^{-4}\right)$ and 'Ambar' $\left(4.22 \mathrm{~mm}^{2} 10^{-4}\right)$, and in the control these were the varieties 'Polina' $\left(2.59 \mathrm{~mm}^{2} 10^{-}\right.$ $\left.{ }^{4}\right)$ and 'Ambar' $\left(2.62 \mathrm{~mm}^{2} 10^{-4}\right)$. The largest total area of the leaf conducting system under conditions of insufficient and optimal moisture was identified in the variety 'Ambar'. The analysis of the data showed that among 13 studied winter wheat samples seven genotypes had higher values of the leaf conducting system in comparison with the variety-classifier 'Asket'. The outflow of assimilants from the vegetative mass to the generative mass directly depends on the power of the leaf conducting system, which affects ripening and kernel weight per head [11, 12]. The analysis of the obtained data showed that the development degree of the leaf conducting system correlated with kernel weight per head.

The values of this correlation are as follows: the more developed the leaf conducting system, the larger the kernel weight per head $[13,14,15]$. The maximum values of the area of the leaf conducting system and the kernel weight per head were identified in the varieties 'Krasa Dona' (4.01 $\mathrm{mm}^{2} 10^{-4}$ and $0.37 \mathrm{~g}$ ) and 'Ambar' (4.22 $\mathrm{mm}^{2} 10^{-4}$ and $0.39 \mathrm{~g}$ ) (Figure 3). 


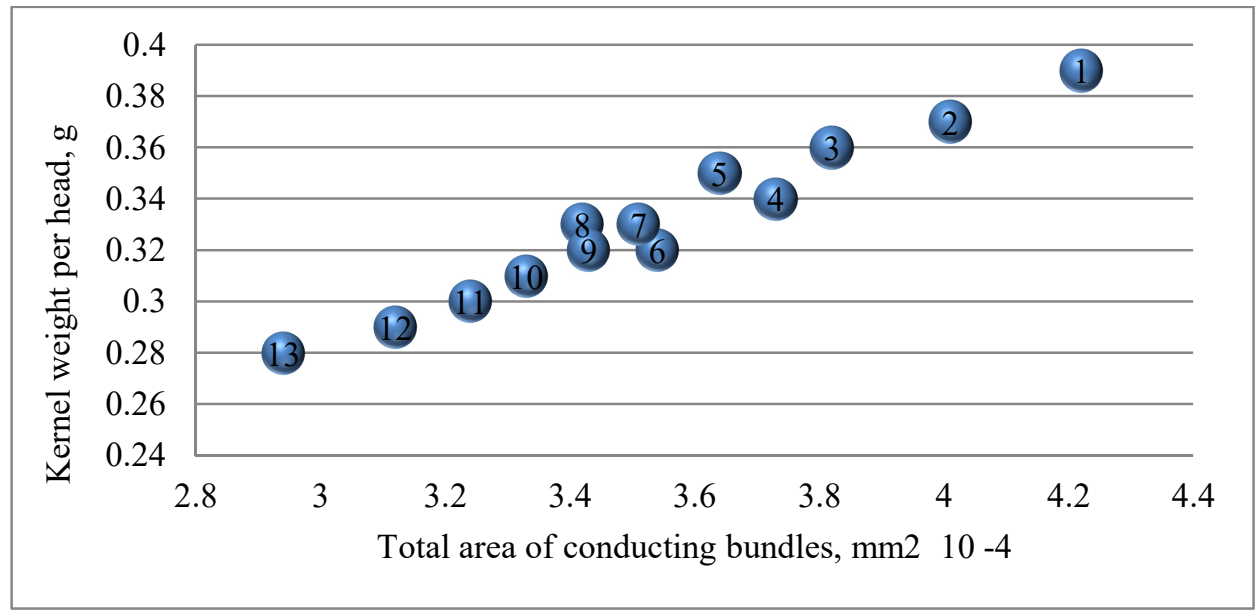

Fig. 3. The correlation of the total area of the leaf conducting system and the kernel weight per head of winter wheat in conditions of insufficient moisture supply.
1. Ambar
5. Zhavoronok
9. Etyud
13. Polina
2. Krasa Dona
6. Shef
10. $1756 / 13$
3. Luchezar
7. Donskaya Step
11. Volny Don
4. $1232 / 13$
8. Asket
12. $586 / 13$

There was identified a large correlation between leaf conducting system and kernel weight per main head $(\mathrm{r}=0,89 \pm 0,06)$.

The largest kernel weight per head and the largest area of the stem conducting system was determined in the varieties 'Ambar', 'Krasa Dona' and 'Luchezar'.

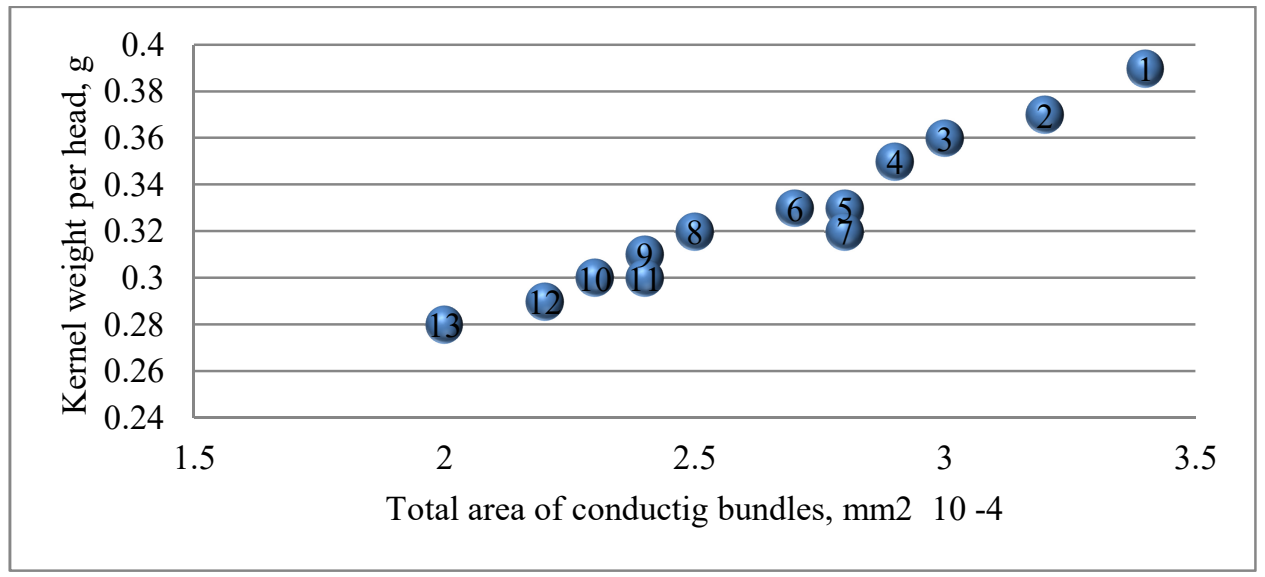

Fig. 4. The correlation of the total area of the stem conducting system and the kernel weight per head of winter wheat in conditions of insufficient moisture supply.
1. Ambar
5. Donskaya Step
9.1756/13
2. Krasa Dona
6. Asket
10. Shef
3. Luchezar
7. $1232 / 13$
11. Volny Don
4. Zhavoronok
8. Etyud
12. $586 / 13$

13. Polina 


\section{Conclusions}

Thus, the current study has proved that the anatomical structure of the adaptive varieties was not adapted to reduce the outflow of nutrients from the leaf and stem to the generative organs, but to increase the intensity of this outflow in comparison with the non-adaptive varieties. The drought tolerant varieties 'Luchesar' $\left(3.82 \mathrm{~mm}^{2} 10^{-4}\right)$, 'Krasa Dona' (4.01 $\left.\mathrm{mm}^{2} 10^{-4}\right)$, 'Ambar' $\left(4.22 \mathrm{~mm}^{2} 10^{-4}\right)$ under conditions of insufficient moisture supply formed a large area of the leaf and stem conducting system compared with less adaptive genotypes and they were capable to supply the head with plastic substances in sufficient quantities.

\section{References}

1. P.V. Michailova, Vogi 14(1) (2010)

2. N.C. Collins, F. Tardieu, R. Tuberosa, Plant Physiolo-gy 147, 469-486 (2008)

3. L. Szabados, A. Savoure, Trends Plant Sci. 15, 89-97 (2010)

4. D.M. Owen, D.J. Williamson, A. Mage-nau, K. Gaus, Nat. Commun. 3, 1256 (2012)

5. A. Nezami, M.R. Soleimani, M. Ziaee, M. Ghodsi, M. Bannayan Aval, Notulae Scientia Biologicae, SciBiol 2(2), 114-120 (2010)

6. D.A. Los, K.S. Mironov, S.I. Allakhverdiev, Photosynth. Res. 116(2-3), 489-509 (2013)

7. C.F. Longin, J. Muhleisen, H.P. Maurer, et al., Theor Appl Genet. 125(6), 1087-1096 (2012)

8. M. Lonbani, Agronomy Research. 9(1-2), 315-329 (2011)

9. S. Lehmann, D. Funck, L. Szabados, D. Rentsch, Amino acids. 39, 949-962 (2010)

10. I. Kutlu, G. Kinac, Journal of Tekirdag Agricultural Faculty 7(2), 95-103 (2010)

11. N. Khalifeie, G. Mohammadi Nejad, Advances in Natural and Applied Sciences 6(2), 206-212 (2012)

12. I.G. Grebennikova, A.F. Aleynikov, P.I. Stepochkin, Bulgarian J. Agricultural Science 17(6), 755-759 (2011)

13. N. Fayaz, A. Arzani, Crop Breeding Journal 1(1), 1-12 (2011)

14. A. Bocian, A. Kosmala, M. Rapacz, B. Jurczyk, Ł Marczak, Z. Zwierzykowski, Journal of Plant Physiology 168, 1271 - 1279 (2011)

15. S.A.R. Hammad, O.A.M.Ali, Annals of Agricultural Sciences 59, 133 -145 (2014) 